Diese Publikation wurde zuerst veröffentlicht in/this publication has been published first in:

Ehrlich, Kornelia; Kriszan, Agnes; Lang, Thilo (2012): Urban Development in Central and Eastern

Europe - Between Peripheralization and Centralization?, disP - The Planning Review, 48: 2, S. 77-92. 


\title{
Urban Development in Central and Eastern Europe - Between Peripheralization and Centralization?
}

\author{
Kornelia Ehrlich, Agnes Kriszan and Thilo Lang
}

\begin{abstract}
The paper provides a theoretical account of the terms peripheralization and polarization, which are used as conceptual contexts. The authors examine whether spatial development in Central and Eastern Europe can be described as a process of polarization and whether this can be seen as the result of current regional and national spatial policies. Empirically, the paper explores ongoing research projects in Ljubljana, Slovenia and Poznań, Poland in relation to the less dynamic parts of these countries in order to identify further research needs. Viewing spatial development in Slovenia and in the Poznań region from the viewpoint of polarization and peripheralization has opened alternative viewpoints on spatial development. A process-based and dynamic approach to investigating disparities should reflect views on the periphery and the center and their specific interrelationships. The perspective of seeing the processes of centralization and peripheralization as related and the combination of structural and socio-political aspects in the constitution of peripheral and central spaces will advance the current state-of-the-art research on spatial development issues in Central and Eastern Europe.
\end{abstract}

\section{Introduction}

In recent years, spatial development in the new Member States of the European Union has been increasingly described using the concept of polarization. The continuous economic and population growth of metropolitan areas has been accompanied by delayed development or the decline of structurally weak areas and spaces outside large agglomerations. Lately, the increasing social and economic disparities at the regional level have fuelled concerns about further spatial polarization and the peripheralization of nonmetropolitan regions in Central and Eastern European (CEE) countries. ${ }^{1}$ These countries show strong evidence of three main trends: Firstly, an East-West gradient can often be found with the Western parts performing better than their Eastern counterparts; secondly, there are profound differences in development between cen- tral urban regions and peripheral rural regions with the urban regions performing much better, and thirdly, these countries demonstrate strong trends towards polarization between their main metropolitan area (usually the national capital) and the rest of the country (Dubois et al 2oo8). Only one or perhaps a few strong economic engines stand against a large number of poor performers, and these (new) peripheries can no longer be described in terms of earlier categories linked to rurality and poor accessibility. ${ }^{2} \mathrm{Nev}$ ertheless, at the national level, the gap between old and new Member States is closing.

However, this gap is closing at the expense of increasing disparities within CEE countries. In fact, the economic development of individual regions relative to others increased sharply between 2000 and 2007 in all CEE countries (see Fig. I). Moreover, a number of scholars have argued that in recent decades, regional policy in the EU has become increasingly dominated by neo-liberal thinking, which has furthered processes of socio-spatial polarization (Krätke r 995 , Scott, Storper 2003, Weichhart 20o8). Prevailing negative experience from the period of centralized planned economies has led to a skeptical perception of any public sector interventions and a turn towards neo-liberal policies in CEE countries during the transformation period (Bohle 2oo6, Aligica, Evans 2009).

After providing an account of what we understand as peripheralization and the specific conceptual context we refer to in this paper, we examine whether spatial development in CEE countries can actually be described as a process of polarization and whether this can be seen as the result of current regional and national spatial policies. Empirically, we draw on ongoing case studies in an exploratory way and see them in the light of the peripheralization approach. To identify further research needs, we describe exemplary processes of spatial development in Ljubljana, Slovenia and Poznań, Poland in relation to the less dynamic parts of these countries. We present perceptions of center and periphery from different perspectives: in the case of Poznań, from a peripheral viewpoint and in the case of Ljubljana, from the capital city's point
Kornelia Ehrlich has studied in Leipzig and Salamanca (Spain) and holds a diploma in cultural studies. Since 2008 she is working as a research associate at the Leibniz-Institute for Regional Geography (IfL) and is preparing her PhD at the Humboldt University Berlin, Institute for European Ethnology. Her current research interests include urban development, Europeanisation and post-socialist/post-colonial practices.

Agnes Kriszan, consultant for foreign trade at the Chamber of Industry and Commerce in Neubrandenburg, holds a diploma and $\mathrm{PhD}$ in social geography. She has worked for eight years as research associate at the LeibnizInstitute for Regional Geography (IfL), focusing her work on processes of regional development in Poland.

Dr. Thilo Lang has studied and worked in Kaiserslautern, Hamburg, Berlin, Potsdam, Sheffield and Durham (UK) before joining theLeibniz-Institute for Regional Geography (IfL) in Leipzig in 2009 where he turned head of the department Regional Geography of Europe. His current research interests include sociospatial processes of multiple peripheralisation, innovation outside of agglomerations, brain drain and return migration. 
Fig. I: GDP per capita in CEE countries 2000 and 2007 (Source: Eurofutures, data source: Eurostat)
Fig. 2: Poznań and Ljubljana in Central Europe.

(Source: Leibniz Institute for Regional Geography (LeibnizInstitut für Länderkunde - IfL
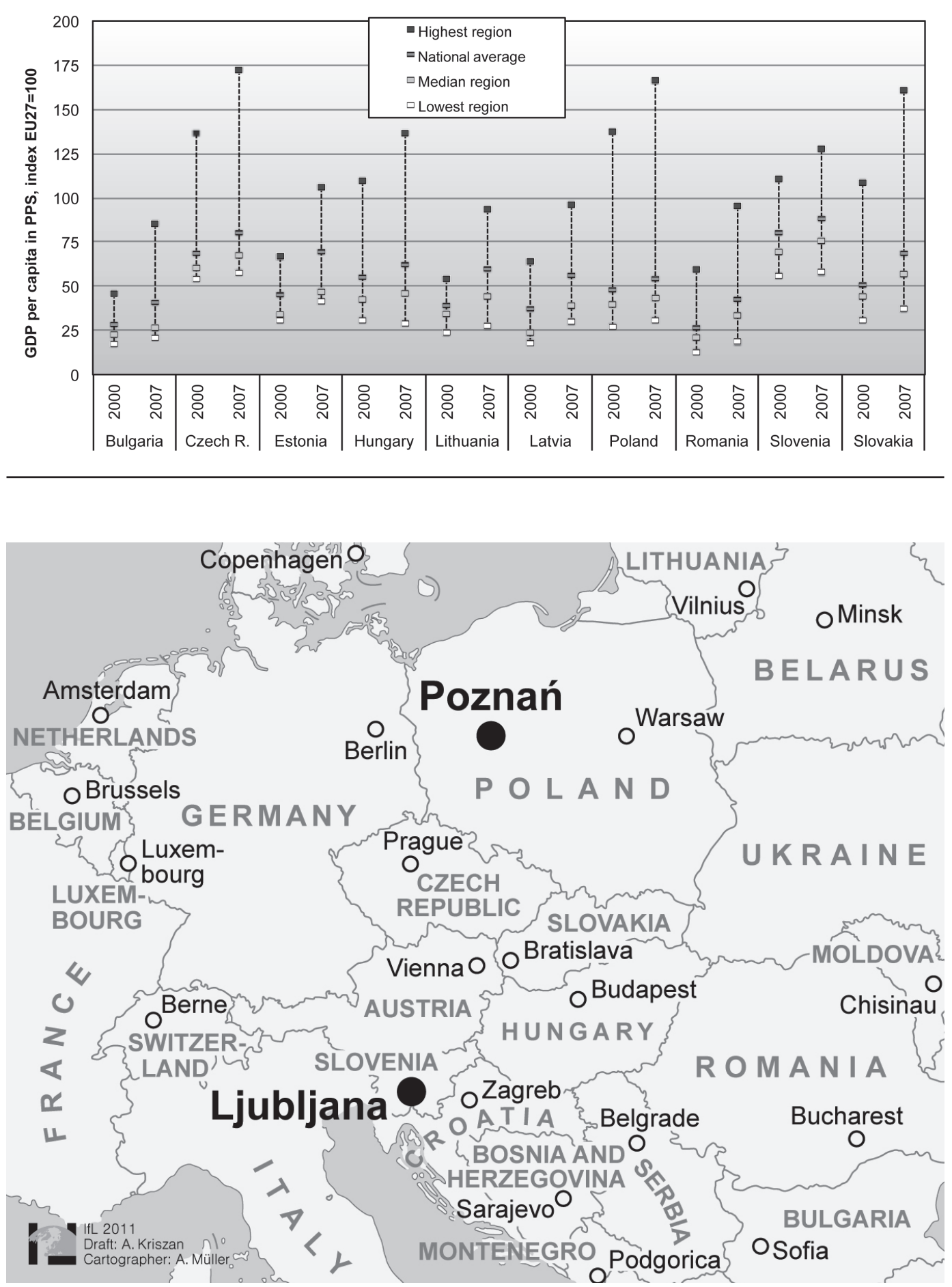

of view. Both city-regions have been subject to growth processes, particularly in demographic and economic terms, and are thus "winners" of a centralization process, however, these processes also resulted in adverse developments in other areas of these countries. How is this tension indicated in these two case studies?

The paper concludes with an assessment of national and regional policies in both coun- tries in relation to the identified processes of centralization and polarization, as well as open research questions affiliated with our theoretical approach. The theoretical framework stems from a current research cluster at the Leibniz Institute for Regional Geography, to which the authors are affiliated, and the case studies are part of two on-going projects of the authors (Borsig et al 2о го, Ehrlich 2or I). 


\section{Peripheralization and Spatial Polarization as Concepts in Urban and Regional Studies}

Remote or marginal areas of Europe and the world, such as islands, mountains, borders, former industrial sites, and rural and structurally weak areas are often perceived as peripheral. The concepts of peripheries and processes of peripheralization (linked to depopulation, disintegration in the globalization of markets, cultures and values, continuous economic underperformance or shortage of investment capital, etc.) are not static and isolated. Some peripheries have a constant character due to their extremely remote location and low population density, severe climatic conditions, and a higher share of less favorable areas for agriculture, etc. (Mose, Brodda 2004). Periphery, however, is a multidimensional concept. Definitions and understandings of the concept vary (see Leimgruber ı 994, 20o4; Schmidt r 998; Havlíček et al 2008 ). One of the key issues for spatial research is to identify and understand differences in the definition, social construction and representations of peripheries. The way in which peripheries are socially understood is influenced by political traditions, historical conditions, former paths of economic development, and political frameworks.

The analytical concept of peripheralization facilitates a relational understanding of spatial disparities and supplements the structural research approaches currently predominantly applied in regional studies. It has a better potential to detect processes leading to social and economic disparities in CEE countries. As the relationship of center and periphery is basic to the concept, peripheralization implies processes of centralization and polarization: The logic and dynamics of spatial centralization determine the peripheralization of other spaces by attracting population, economic productivity and infrastructural functions - to the disadvantage of other regions (Keim 2006). Furthermore, this polarization is enhanced by a national discourse that places higher value on particular regions and developments and thereby devalues others.

Komlosy (1988) defines regional peripheralization as the growing dependence of disadvantaged regions on the center; Blowers and Leroy stress the simultaneity of a number of features constituting peripheries, such as distance, economic weakness and lack of political power (Blowers, Leroy i 994). In addition, the dynamic differentiation into "winning" and "losing" regions overlaps at different spatial scales (producing regional, national and global $\operatorname{disP}{ }_{1} 89 \cdot 2 / 20 I 2$

ing of peripheralization, going beyond earlier ideas of polarization (Myrdal I957; Hirschman I 958 ; Krugman r99 I), has the potential to define starting points for research on regional development issues in the light of disparity formation and uneven spatial development.

\section{Researching Processes Instead of Structures}

The emphasis on spatially relevant processes rather than the resulting spatial structures makes it easier to broach issues of discursive (political) attribution with regard to the relationship between normative societal orientations and "real" developments. Peripheries should be seen as the result of processes of peripheralization and not as structural conditions of space (see also Beetz 20o8). The emergence of peripheries and disparities is also a question of power, not so much individual power, but rather power in the overall societal discourse, within which peripheries are or become meaningless. Actors representing peripheries do not have a say in the overall (regional) policy discourse nor do they have any access to relevant decision-making networks. When it comes to location decisions for firms, functions and infrastructures, other regions are served, and the structural problems of peripheral regions are not recognized from the outside or not seen as relevant. "Sich nicht (mehr) gegen Benachteiligungen wehren zu können, das bedeutet Peripherie" (Not being able to defend yourself from discrimination any more means that you're peripheral) (Neu 20o6: ı3). Similarly, Blowers and Leroy see "powerlessness" as a central feature of periphery, which is strengthened by a "culture of acceptance" based on values that "predispose the community to inaction" (Blowers, Leroy I 994: 204f).

However, defining centrality is part of social discourse, political negotiations and medial orchestrations (cf. Beetz 2008). Within this process, particular forms of life and work, as well as images and paradigms of spatial development, are seen as better, more reasonable or more significant than others. The relationship of center and periphery thus mirrors the societal construction of spatial order. The discourse around this order, however, is only implicit, in particular, as the definitions of center and periphery seem to be based on structural indicators supporting the belief that this follows a kind of natural order. Very rarely, there is an explicit debate 
about the margins and thresholds leading to the prescription of a spatial category. ${ }^{3}$

Currently, dominant dichotomous ideas of urban and rural, central and peripheral, leading and lagging or growing and declining areas determine spatial development as well as our methodological, theoretical and normative approaches to regional studies. These dichotomies are useful to reduce complexity in modern world research. However, there might be other ways to reduce complexity, as using dichotomous categories also carries some methodological and theoretical traps. In trying to overcome these strong categories, a process-based and $\mathrm{dy}$ namic understanding of urban and regional research - as suggested in using concepts such as peripheralization - at least offers promising alternative approaches to up-to-date questions of urban and regional geography that seem worth following. In general, space cannot be tackled as an absolute category and should be seen as socially produced (Lefebvre I 99 I) and dynamic; centers and peripheries are made by and depend on their contexts. Peripheries are dynamic and dependent on scale and time (Smith i 995 ).

Comparative research on CEE states reflecting these multi-faceted viewpoints is very rare. Due to the relatively short duration of full EU membership of the CEE countries, there is little experience or knowledge of the territorial impact of EU and national policies, e.g., relating to the polarization of urban and regional systems in CEE states into strong, central (mainly metropolitan) areas on the one hand and peripheral areas with negative socio-economic and demographic development trajectories on the other. A working hypothesis is that there has been a strong interrelationship, especially when it comes to infrastructure policies and general market-oriented, neo-liberal positions. However, it is already clear that the causal processes are multi-dimensional and that regional policy has only a share in this complex system. Polarization and peripheralization characterize a number of overlapping spatially relevant processes:

- As a consequence of the decline of traditional industries, some areas are having increasing difficulty finding their place in the world economy and experiencing a growing dependence on transfer payments, as a competitive economic base has not yet (re-) emerged; this results not only in economic dependence and selective mobility of capital, but also in one-sided political dependence with unbalanced power relationships. - The population in CEE tends to further concentrate in a diminishing number of prosperous areas, in contrast to a growing number of regions suffering population decline; thereby intra- and inter-regional migration patterns overlap with international migration on the basis of age-selectivity/ labor mobility and an overall decline of birth rates, which is particularly sharp in CEE.

- More recent (neo-liberal) positions have led regional policy to focus on larger and more prosperous centers and metropolitan areas, thus furthering socio-spatial polarization as well as other areas' loss of importance.

- EU and national infrastructural policy have favored some regions, whereas others have become more remote due to disinvestment in transport infrastructures; infrastructure is increasingly centralized (e.g., the restructuring of high-speed transport networks alters the (relative) position of particular areas), and service provision is reduced in quality and quantity in remote places, leading to a loss of urban functions and problems of accessibility.

- Particular regions, e.g., some areas on the external border of the EU, are shaped by peripheralization processes on different spatial scales (global, EU, national, regional); many share typical structural problems of industrial decline and rural depopulation.

Aspects of the social construction of space affect the above-mentioned trends and thus the emergence of peripheries and the polarization of space in CEE nations. In principle, the terms periphery or peripheralization are neutral. However, due to the discursive negotiation of spatial categories, spatial structures and land use, spaces become normatively charged (and in part negatively labeled). High rates of outmigration do not constitute negative images of depopulation areas alone, but in combination with stigmatization in public discourse and in relation to other spaces.

Beetz depicts the order of center and periphery in the context of the dominance of centers in societal discourse. Here the centers can consistently portray themselves as spaces of modernity and progress. Consequently, in symbolic terms, it is of the highest importance for spaces to be part of the corporate mainstream (Beetz 20o8). A good example is the current debate on metropolitan regions in Germany (see Schmitt 2007), which parallels similar political discourses in the UK, Poland and Rumania. This indicates that not only structural trends are relevant to socio-spatial polarization (Blowers, Leroy r 994), but also "soft" factors, such as political dependence and power, internal and external images, and normative and political ideas about spaces (Lang 20IO). 


\section{The Case of Poznan}

Since the political and economic turn in 1989 , large cities have been the main drivers of economic growth in Poland. Undoubtedly, Warsaw has to be named first in the context of economic processes of centralization in post-socialist Poland. Notwithstanding its prominent role as the state's capital, Warsaw has developed into a competitive center of control, innovation and communication, or, as Smętkowski and Gorzelak (2008) and Kaczmarek and Mikula (2007) describe it, into a metropolitan region of European significance. Warsaw is increasingly dominating economic development dynamics in Poland, as the gap in GDP per capita between the capital and the other large cities does not appear to be closing (see Fig. 3). Furthermore, these cities are increasingly subject to metropolization processes (Jałowiecki 2006 ; Kaczmarek, Mikuła 2007), (see Fig. 5).

"Observation of the transformation processes in Poland indicates that metropolitan areas are developing faster than the voivodships (provinces) they are situated in. In particular, this is true with regard to Kraków, Warsaw and Poznań. In addition to that, the gap between the cities and the areas surrounding them is also widening at a fast pace. Depending on the size of a given city, its radius of influence reaches $20-50 \mathrm{~km}$. Outside this area, stagnation or even regression can be observed, which is due to the 'draining' of the area of human and material resources" (Jałowiecki 20o6: 79).

Hence, we are witnessing a process of centralization on the national and regional levels, leading to the peripheralization of areas outside of these core growth areas.
Before the fall of the socialist regime, Poznań already had a well-developed economy, although - due to technological gaps and a low level of innovativeness - it was never as competitive as the economies in Western European cities (Parysek, Mierzejewska 2006). However, the favorable economic framework conditions (diversified economic structure, skilled labor force, exceptional work ethic), together with the (western) central geographical location, attracted foreign investors to enter Poznań as a pathfinder to new markets and thus to bankroll the modernization of the city's economy (Parysek, Mierzejewska 2oo6; Stryjakiewicz et al. 2007). Since r $99^{\circ}$, altogether 6.3 billion USD have been invested as foreign direct investments (FDI), $70 \%$ of them coming from Germany, Great Britain, the US, France and Japan (UMP 2009).

Today, Poznan is perceived to be "one of the oldest, largest and fastest growing cities in Poland" (Parysek, Mierzejewska 20o6: 29I). It is characterized by a diversified manufacturing sector and prospering service branches, contributing about $3 \%$ to the national value added (2008) (GUS 20 Io). Along with Warsaw, Poznań has recently become one of the most dynamic and economically powerful cities in Poland, offering jobs for nearly $30 \%$ of all employed persons in Wielkopolska voivodeship (UMP 2009). The radius for daily commuting reaches up to $250 \mathrm{~km}$, although the predominant part of commuters (about $85 \%$ ) lives within a roo $\mathrm{km}$ circle $/ 50 \mathrm{~km}$ radius around Poznań (USP 2 o ob).

However, the inner city of Poznań, like other large Polish towns, is suffering from depopulation which, according to Parysek and

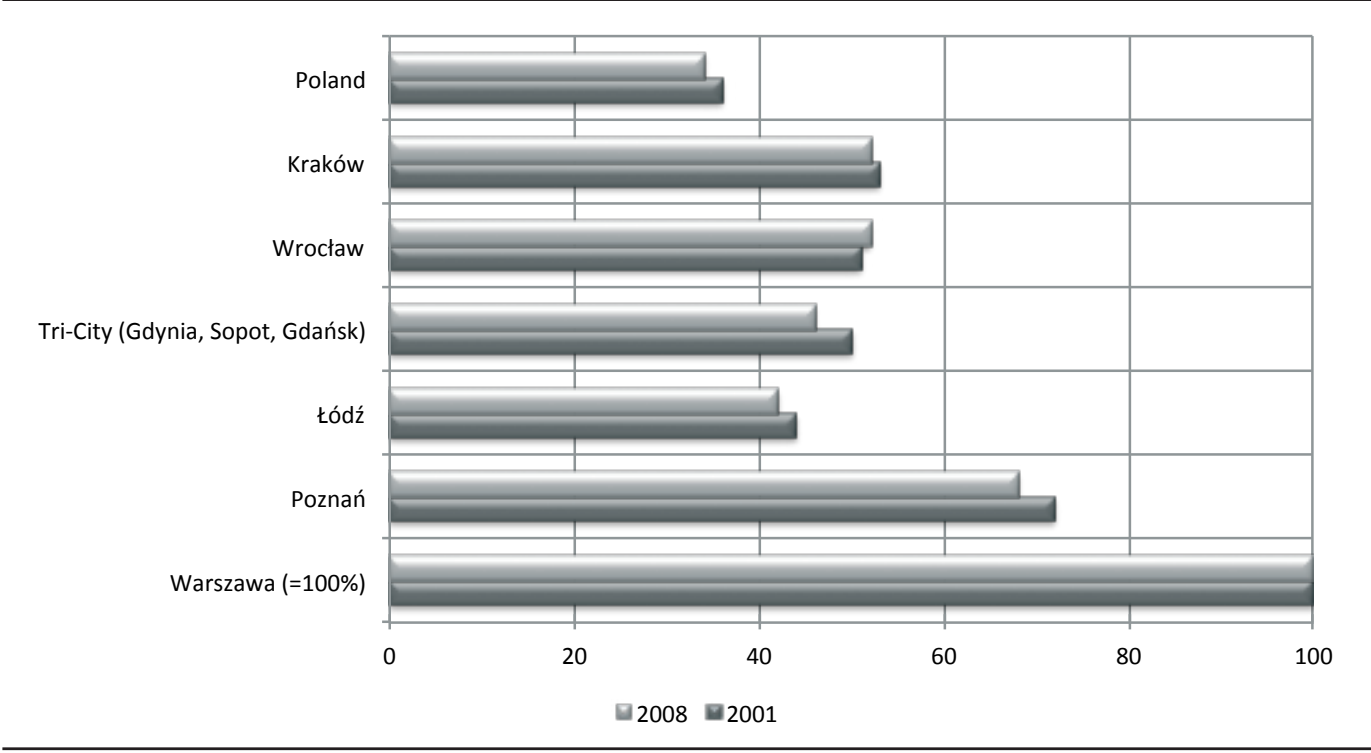

Fig. 3: GDP per capita in selected Polish towns. (Source: Author's calculation based on GUS 2004,2010 ) 
Tab. I: Population development in Poznań Metropolitan Region (PMR) I996-2008.

Source: Author's calculation based on GUS Bank of Local Data [www.stat.gov.pl])

\begin{tabular}{|c|c|c|c|c|c|}
\hline & 1996 & 2000 & 2004 & 2008 & $\begin{array}{l}\text { Change } \\
1996-2008(\%)\end{array}$ \\
\hline $\begin{array}{l}\text { PMR } \\
\text { of which }\end{array}$ & 823.906 & 842.772 & 851.702 & 868.654 & +5.4 \\
\hline Poznań city & 580.831 & 582.254 & 570.778 & 557.264 & -4.1 \\
\hline Other municipalities & 243.075 & 260.518 & 280.924 & 311.390 & +28.1 \\
\hline
\end{tabular}

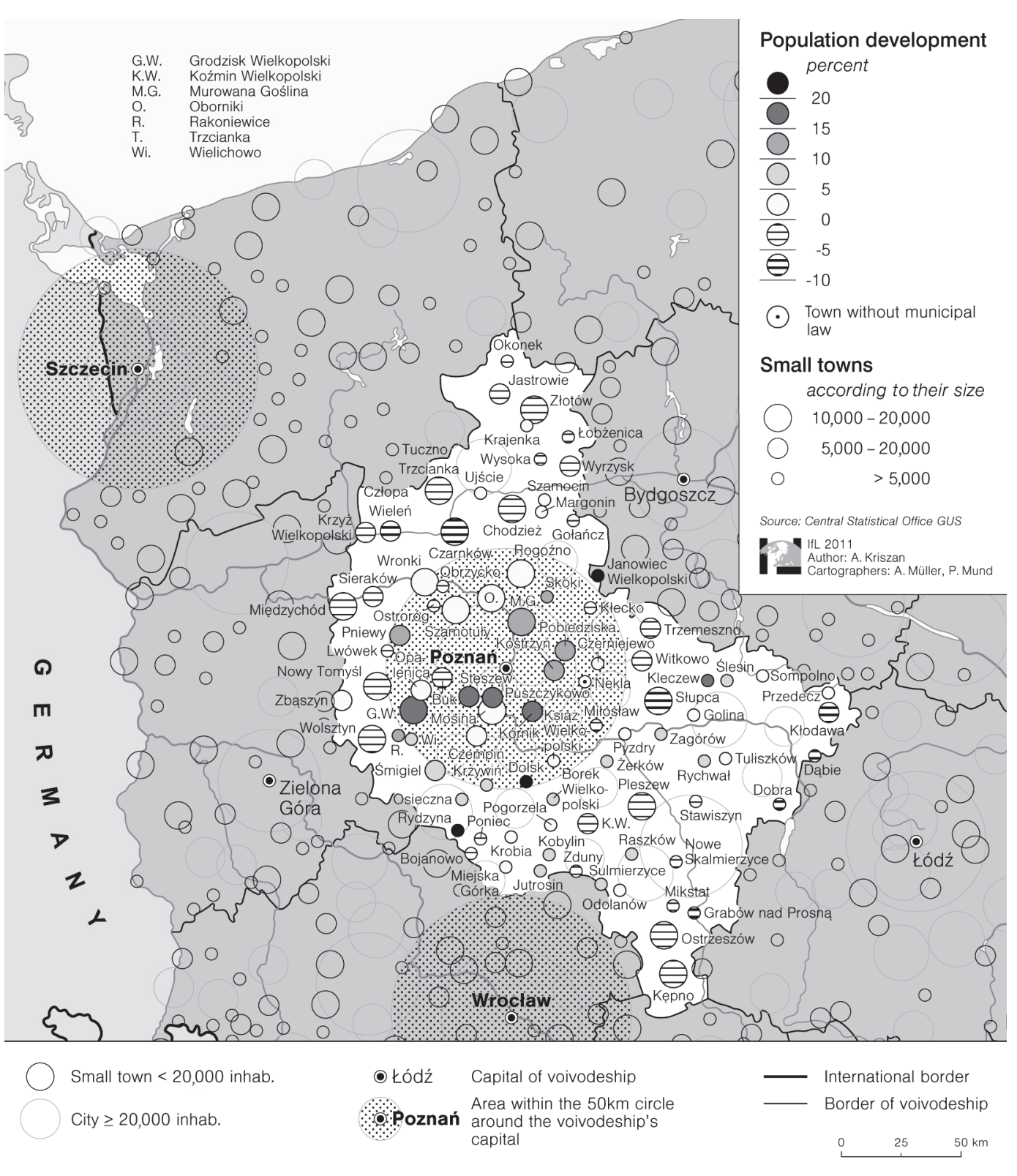

Fig. 4: Population developmen in the voivodship of Wielkopolska r 995-20o8.

(Source: IfL, data source: Central Statistical Office GUS)

Mierzejewska (2006), can be attributed to three interdependent processes: (I) declining natural growth rates, (2) declining in-migration from the countryside and (3) increasing movement of the resident population towards the suburban fringes. The depopulation of Poznań has to be seen as the result of housing shortages that induce young families especially to move to the suburbs. As a result, the core area of the so-called Poznań Metropolitan Region (PMR $)^{4}$ has registered considerable population losses, while the suburban municipalities have gained significantly in population (see Table I and Figure 4). 
Due to its economic and socio-cultural importance, PMR constitutes the core of the voivodeship, while the rest is dominated by rather small settlements. More than $80 \%$ of all towns in Wielkopolska have less than 20,000 inhabitants (Konecka-Szydłowska 2oog). Even if their demographic and economic potential cannot be compared to that of larger urban centers, their significance for regional development should not be underestimated. Considering the shortage of medium-sized cities and the vast number and spatial distribution of small towns in Wielkopolska, the latter often fulfill trans-local and even regional functions and thus appear as growth poles for development (Lamprecht 2004). Whereas the development perspectives of small towns are influenced by a number of factors, probably the most important factor in the Wielkopolska voivodeship is their relationship to Poznań, the main center of social and economic activity. The development dynamics of small towns are most close to the metropolitan core. Consequently, in the northern part of the voivodeship, the Pilski subregion, GVA per capita in 2008 amounted to $26,044 \mathrm{zl}$, which was significantly lower than in the Poznań city municipality $(67,045 \mathrm{zl}) .^{5}$ Decision-makers argue that these economic disparities have to be seen as a result of the underdeveloped transport system (especially the lack of motorways and fast-track railways), which has insufficient links between economically weak regions and the urban centers.

To date, Poznań has kept its role as the regional center of investments, generally to the disadvantage of small cities outside of Poznań's sphere of influence. For instance, Złotowski poviat, the most northern district in Wielkopolska, although not suffering from large-scale depopulation in the recent past, is the district with the highest registered unemployment: by the end of 2009 , the unemployment rate amounted to I $9.8 \%$, whereas the average of the voivodeship was 9.1\% (and Poznań 3.2\%) (USP 2or oa). In light of the infrastructural centrality of Poznań, districts like Złotowski poviat are not preferred destinations for large-scale ventures - neither foreign nor domestic investments. Empirical evidence from research ${ }^{6}$ in small towns of this part of Wielkopolska voivodeship shows that local authorities meanwhile are well aware of their situation (i. e., peripherality in terms of accessibility and infrastructure, but also with regard to dependency on external decisions). On a local level, there is a rising tendency to abandon the dream of a large-scale enterprise that is willing to realize big investments. An increasing number of local authorities is thus developing strategies to cope with the fate of peripheralization, relying for the most part on endogenous resources like human and social capital. Generally, the primary aim of these strategies is to stabilize economic development and enhance the quality of living by improving the technical, social and cultural infrastructure.

The divide between Poznań and the geographically remote regions outside the PMR cannot be bridged without efficient political support. Contemporary development policies on the national and regional levels though, are rather oriented towards polarized development forms (Bański 2007), furthering on-going processes of centralization, although they contemporaneously acknowledge the polycentric character of the Polish settlement system (Concept for National Spatial Planning 2005, see Fig. 5). They clearly follow the neo-liberal idea of growth spillovers to the benefit of the wider region, assuming that innovations and other developmental factors will gradually spread from growth areas to what may generally be considered peripheries, with the ultimate goal of achieving a convergence of regional development. However, as Bański puts it, "Poland seems to be at the initial stage of that process, and the effects of 'sucking out' still prevail over the effects of "spreading out" (Bański 2007: 79).

The Development Strategy of the Wielkopolska Region by 2020 , for instance, perceives Poznań as a growth engine and pacesetter that has to be strongly supported in order to ensure the prosperity of the whole region (p. 3i ). The policy, however, has failed considerably to reach out into the whole region and only a metropolitan core benefited from this policy - to the disadvantage of more remote areas. The document disregards the supplementary role of small towns and other small settlements, although it acknowledges existing disparities between the Poznań agglomeration and the remaining parts of the voivodeship.

This neglect of small towns in development policies can also be detected on the national level. The National Development Strategy 2007 2015 does not refer to the role of small and medium-sized towns at all. Only the National Cohesion Strategy 2007-2013 specifies the relevance of small towns as potential regional growth poles and suggests the improvement of their junction to larger cities.

The dilemma from a policy perspective is a lack of definition and spatial conceptualization of small towns: they are neither seen as being decidedly urban nor are they perceived as being 
Fig. 5: Concept for the spatial development of Poland.

(Source: based on Koncepcja polityki przestrzennego zagospodarowania kraju $200 \mathrm{I}$, adapted in Bański 2007: 67)
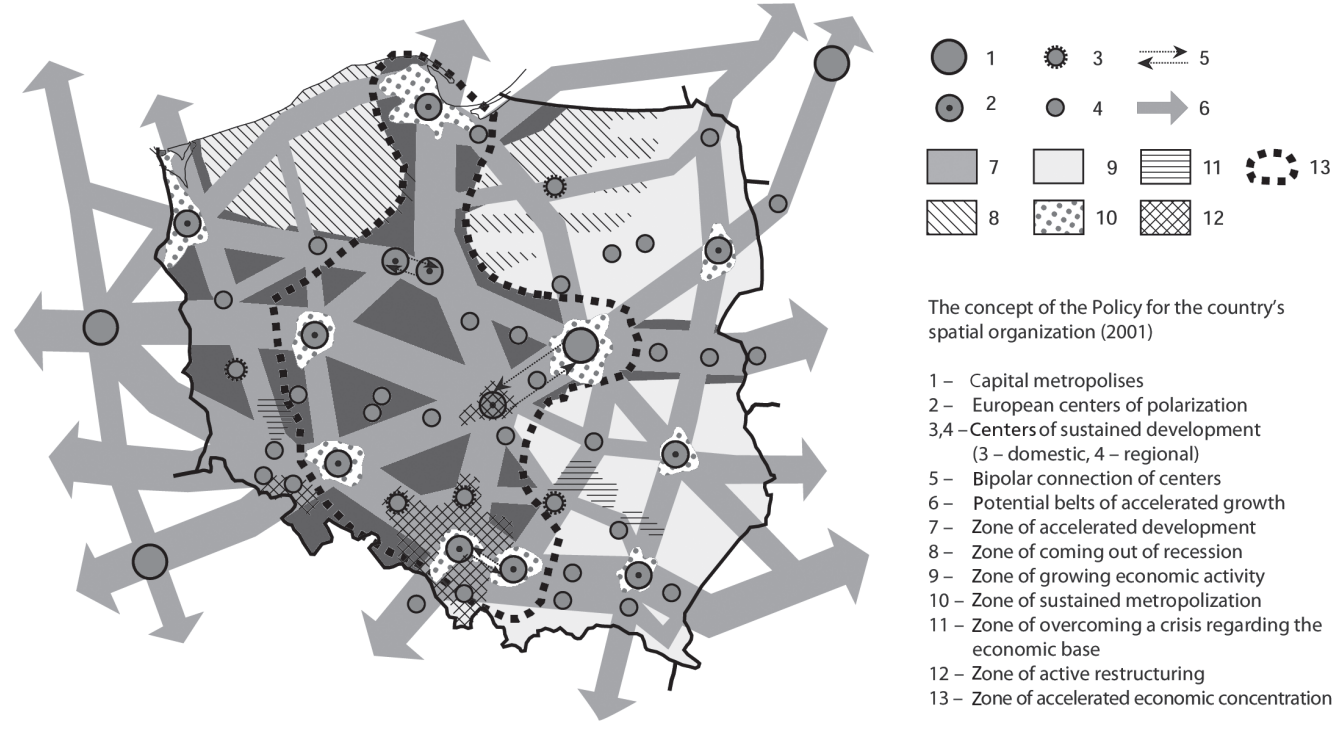

The concept of the Policy for the country's spatial organization (2001)

1 - Capital metropolises

2 - European centers of polarization

3,4 -Centers of sustained development

(3- domestic, 4-regional)

- Bipolar connection of centers

6 - Potential belts of accelerated growth

7 - Zone of accelerated development

8 - Zone of coming out of recession

9 - Zone of growing economic activity

10 - Zone of sustained metropolization

- Zone of overcoming a crisis regarding the

12 - Zone of active restructuring

13 - Zone of accelerated economic concentration rural settlements. Regional policy, however, only works in these dichotomous categories, hindering the development of a more active role for small towns in development policies. Furthermore, Polish spatial planning policy, unlike, for example, the German case, is not legally bound to the primacy of establishing equal living conditions throughout the territory. Thus, e.g., support for comprehensive infrastructure measures providing better development possibilities for small towns is not at the top of the political agendas.

Peripheralization processes of small towns in general can be traced back to the early postwar period of the i 950 s when urbanization in Poland was decisively influenced by industrialization (Szymańska, Matczak 2002). The first socialist industrialization plan, the so-called "sixyear-plan“, although aiming for a more equal distribution of productive forces in space, resulted in only a limited number of small towns (especially in the industrialized parts of Poland) being privileged to benefit from state support Hence, despite the ambitious aims of the development program, most smaller towns could not profit from the state-induced industrialization and became subject to communist collectivization, eliminating traditional handicrafts, private services and particularly private trade - the primary economic basis of every small town. As a result, during the socialist period out-migration towards the large centers increased and the share of people living in small towns decreased significantly (Parysek, Kotus i 997, Szymańska, Matczak 2002). The depopulation processes stopped after the political and economic turn in 1989 , when nearly all small towns witnessed a functional renaissance and a general improvement of their socio-economic situation. To date, even small towns in peripheral and structurally weak parts of the voivodeship have registered only moderate depopulation processes.

The divergence of development paths in Polish small towns has to be seen as a result of different dynamics concerning economic development, demographic changes, developments on the labor market, progress in privatization and accumulation of capital that to a different general performance of small towns in Poland (Heffner 2005; Borsig 2007). Generally, small towns in the suburban fringes of large cities emerged as "winners of transformation" because they could profit from significant growth spillovers. Geographically remote small towns, in contrast, in many cases had to suffer from economic and social decline as they weren't provided with a development idea beyond integrating into the wider metropolitan region.

However, despite economic and structural deficits and political disregard, small towns have proved throughout the years to be rather stable elements of the Polish settlement system. With regard to constantly rising territorial disparities in Poland (OECD 2008) and their quantitative dominance in the form of settlements, small towns - especially those in rural and sparsely inhabited areas - should receive better support as they have the potential to balance disparities and to contribute to better economic and social cohesion. On a local level, first attempts to follow alternative and more locally based paths of development can be seen. This, however, also 
requires a well-reflected approach to regional policy, not just aiming at the support of metropolitan regions, but also considering the significance and potential of small towns as regional growth poles, which is not yet the case in Poland.

\section{The Case of Ljubljana}

Ljubljana, the capital of Slovenia, has been influenced by different political systems and developments over the last forty years. In the formation of its capital, independence constituted an important caesura. After I 99 I, Ljubljana witnessed a process of functional centralization: most of the administrative, commercial and financial functions were concentrated in Ljubljana (Pichler-Milanovič 2005: 326). ${ }^{7}$ After a phase of urban decline in the r 980 os through suburbanization $^{8}$ (Pichler-Milanovič 20o5: 344) and a general depopulation process after independency (Statistisches Bundesamt i 995: 35), ${ }^{9}$ the population of Slovenia in total and Ljubljana in particular has been growing again since $\mathbf{9} 999$. In 2007 , the Ljubljana urban municipality had ${ }_{2} 67,760$ inhabitants, which is equal to $13.0 \%$ of the entire Slovenian population. ${ }^{10}$ At the beginning of $20 \mathrm{I}$ I, the inhabitant numbers were again higher in Ljubljana $(280,140)^{11}$, whereas the total population of Slovenia had dropped slightly (to 2,05o, I89), meaning a further concentration of the population in Ljubljana, now equaling $13.7 \% .^{12}$ In recent years, Ljubljana can thus be characterized as being in a process of centralization in terms of administrative, financial, economic and demographic functions.

After independence, the spatial landscape of Ljubljana was also transformed through the conversion of former industrial and military sites, the completion of an inner-city motorway, and privatization and deregulation as a consequence of market and structural reforms (Pichler-Milanovič, Zavodnik, Lamovšek 20 I o: 8 I 8). Ljubljana became the prime location for national and international investment and a driver of Slovenia's economic development. Finally, the accession of Slovenia to the European Union in 2004 gave a further push to the development of Ljubljana. The Slovenian capital was finally propelled into global urban competition and attracted further international recognition.

A European-style culture and creativitydriven urban policy was introduced into Slovenian development policies as well as in concrete spatial projects, being visible in Ljubljana in particular and further shifting attention towards Ljubljana as the main creative and inno- vative center of Slovenia. ${ }^{13}$ Furthermore, several public-private partnerships were established in order to build premises that offer apartments, offices as well as production spaces for creative industries (Novi Kolizej, Tabačna City, Śmartinska Partnership).

Finally, several planning documents focus on spatial development with recourse to creativity and culture. In 2002 , the Urban Development Concept for Ljubljana was adopted. In general, it aims at strengthening urban and cultural identity and the stabilization of a continuous urban structure. ${ }^{14}$ The development of the Urban Development Concept was influenced by socio-economic modifications due to the democratization process, the debut of Ljubljana in global competition, the development of new communication and information technologies and the increasing significance of ecological aspects (Dimitrovska Andrews et al. 2007: 427-428). Another document that was adopted was the Spatial Development Plan of the City Municipality of Ljubljana that aims at a "smart urban development" through urban revitalization (Pichler-Milanovič, Zavodnik, Lamovšek 20 г o: 822-823). It also reveals an implicit "creative city" formation of Ljubljana that has been driven by three main factors:

I. Macro-economic reforms during which Ljubljana became the most important site in Slovenia for economic activities and developed into one of the most competitive urban regions in Central Europe (Pichler-Milanovič, Zavodnik, Lamovšek 20I0: 8I 7 ).

2. Concentration of research activities and the role Ljubljana plays as a university center, which offers potential for the development of innovation. 3. Despite (new) international relevance as a capital, due to its size, businesses can easily establish networks and cooperate with research institutes concentrated in Ljubljana.

On the regional level, the Regional Development Program (RDP) was adopted by the Ljubljana Urban Region (LUR) ${ }^{15}$ in 2007 . It determines the development priorities of the region and suggests measures for its realization. ${ }^{16}$ Key parts of the concept support the strengthening of Ljubljana as the region's core. Hence, on the national as well as regional level, the centrality of Ljubljana has increased and led to a strong concentration of all sorts of activities in Ljubljana. These multiple processes of centralization that interfere with the applied polycentric development concept in various Slovenian planning documents make it very difficult for other regions in Slovenia to find their role in the wider urban system and rather prohibit bal- 
anced spatial development. The consequence is spatial polarization. At a first glance, the general spatial development of Slovenia reveals similar trends to those in other CEE countries after the transition period: capital regions and major urban centers have been growing, followed by an increase of their economic, political and demographic significance.

Some scholars argue, however, that this process of accelerated centralization and the strong development focus on Ljubljana as the Slovenian capital should be linked to the so-called $u r$ banization gap (Ravbar 2005: 225) rather than arguing for a general tendency for post-socialist states following neo-liberal policies. In this argument, the reasons for a need to catch-up on urbanization can be seen in the smaller population growth in Slovenian cities throughout/ through industrialization, a weak development of a middle class due to late independence and the importance of agriculture over a long timeframe (part-time farming prevails) ${ }^{17}$ as well as a traditional affinity to rural life. ${ }^{18}$

The fact that, compared to its size, Slovenia still can be seen as one of the most polycentric European countries supports the above argumentation. Polycentric spatial, economic and regional development policies were introduced in the late r 960 s under socialist rule and have again made their way into recent policy programs. Spatial development documents and policies that were established after 2000 include the polycentric concept as a main policy principle; this has also to be seen in the context of the accession of Slovenia to the European Union, since EU documents consider polycentrism to be an instrument to guarantee balanced spatial development (Pichler-Milanovič et al. 20 I I: 5 ).

Although the polycentric concept has been included in various planning documents and policies, insufficient implementation of these policies at the local and regional levels and the lack of spatial planning legislation have led to uneven spatial development. The main urban areas have experienced centralization through economic strengthening and a strong population growth, in particular in the suburban hinterland - where almost half of the Slovenian population is concentrated. The areas outside of these agglomerations can be characterized by a growing functional differentiation, growing development disparities, de-settlement and a decay of the cultural landscape. Concerning population and economic growth, they are lagging behind in comparison to the urban regions (Harteisen 2004: 3-6).

This trend of polarization, in particular between the Ljubljana urban region and other Slovenian regions, has been further exacerbated since 2008 by the economic and financial crisis Outside of Ljubljana, one finds intensive suburbanization along motorways, decline of town centers, urban sprawl, inadequate urban renewal and incomplete local infrastructure provision providing accessibility for rural settlements
Fig. 6: GDP per capita 2007 and population 2008 .

Source: Statistical Office 20 г 0:5, data source: SORS and SMA $)^{19}$

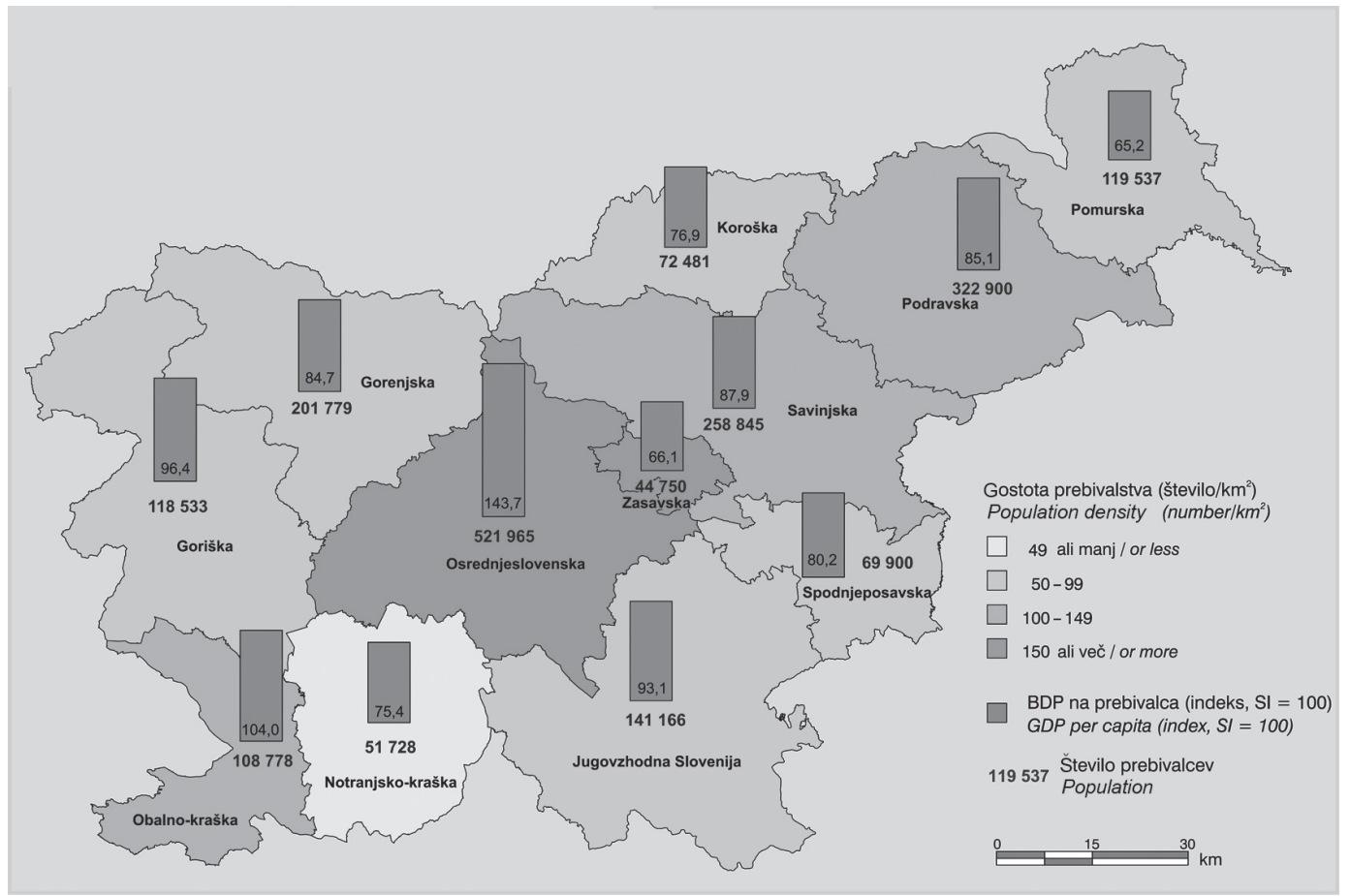


(Pichler-Milanovič et al. 2o г: г6). The Spatial Management Policy of the Republic of Slovenia from 2002 addresses unbalanced spatial development. The policy document reveals several interlinked challenges to be met in the future:

- Stagnation of natural population growth, an aging population and a decrease in the share of the active population.

- Depopulation of border and less developed regions, unbalanced road and rail transport provision.

- Missing modernization of public transport systems in general, economic regression in old industrial areas.

- Gap between the centralized government and the fragmented smaller local authorities.

Hence, there is awareness of the problems of polarization and uneven spatial development, and the document mentions several policy measures for how these challenges shall be counterbalanced:

- Promotion of equivalent development of regions, particularly structurally weaker and border areas.

- Promotion of interregional and cross-border cooperation.

- Redefinition and implementation of the polycentric development of cities and other settlements as development generators in connection with their hinterland.

- Promotion of the development of regional centers.

- Provision of access to resources of common interest by modernizing the public transport system. (Hladnik et al. 2002: 5-8)
The concept of polycentrism, the de-central allocation of services, infrastructure and industry, offers one possibility to counterbalance this trend. Nevertheless, there seems to be a strong ambiguity between policy documents and their realization. Although having included a polycentric strategy and the counterbalancing of peripheralization in different regional and national policies, Ljubljana, and to a lesser extent Maribor and Koper, form a strong axis in Slovenia.

Ljubljana especially has an outstanding position due to its capital status, which is linked with greater centralization. ${ }^{20}$ Most of the administrative and (national) functions are concentrated here, which leads to an increased total number of jobs. And, due to macro-economic reforms, namely, the implementation of a neo-liberal market economy, Ljubljana became the most important place in Slovenia for economic activities furthering spatial polarization. ${ }^{21}$ Consequently, the Spatial Development Strategy of Slovenia, adopted in 2004, formulates the planned development for Ljubljana, Maribor and Koper as the three Slovenian centers with national and international importance in a clear hierarchy:

Ljubljana shall be developed at the national level as the capital and the most important national transport node, with the concentration of the highest functions and institutions, the central business, cultural, and supply activities and services of significance for the entire country.

Maribor, the second largest city, is seen as a national transport node and contains bridging functions to neighboring countries, whereas Ljubljana should play a broader international

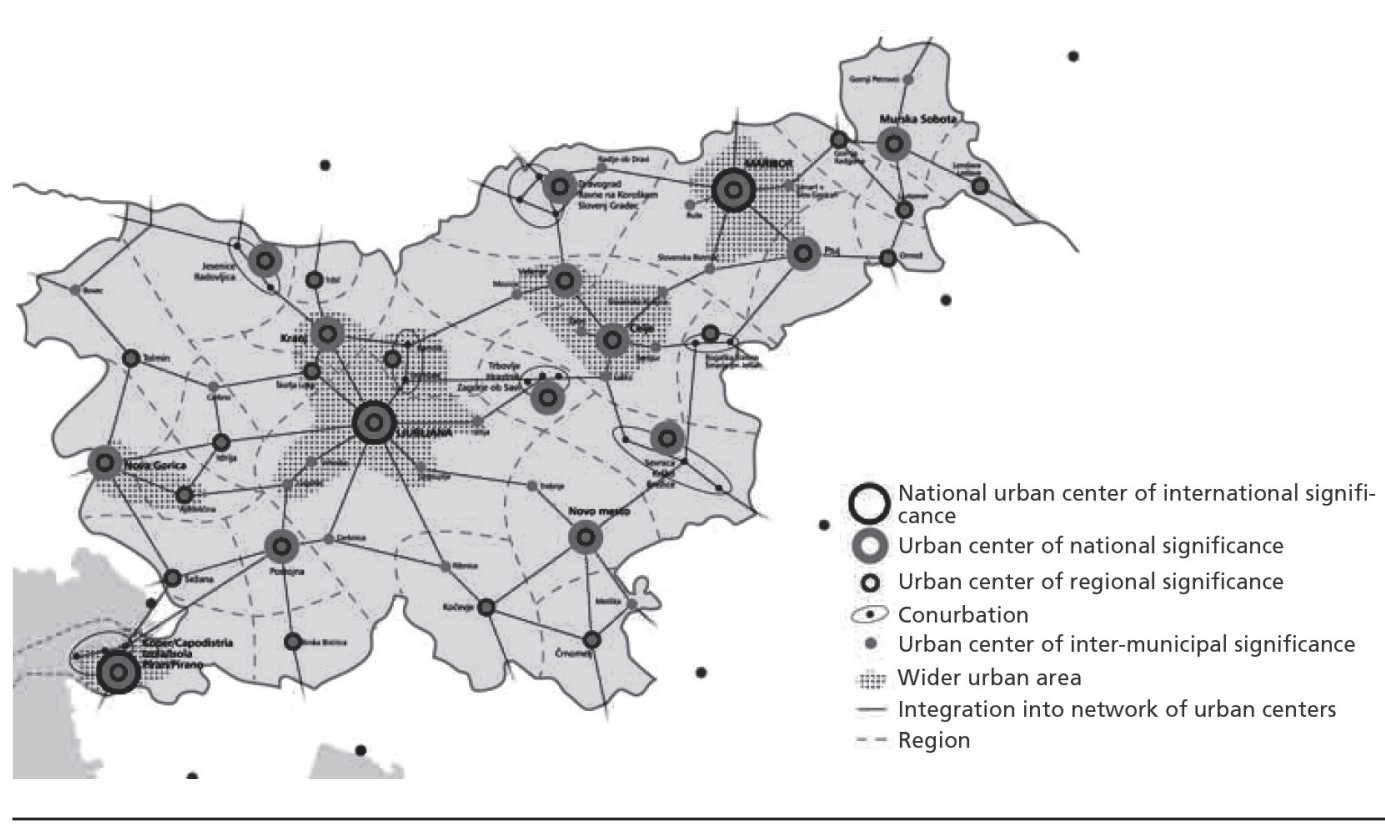

$\operatorname{disP}{ }_{I} 89 \cdot 2 / 20 I 2$
Fig. 7: Polycentric urban system and development of wider urban areas.

(Source: Spatial Development Strategy of Slovenia, p. 24.) 
Fig. 8: Regional development tendencies in Slovenia. Source: based on Potočnik Slavič, 2008 , data source: Institute for Geography, University Ljubljana, 2005.)

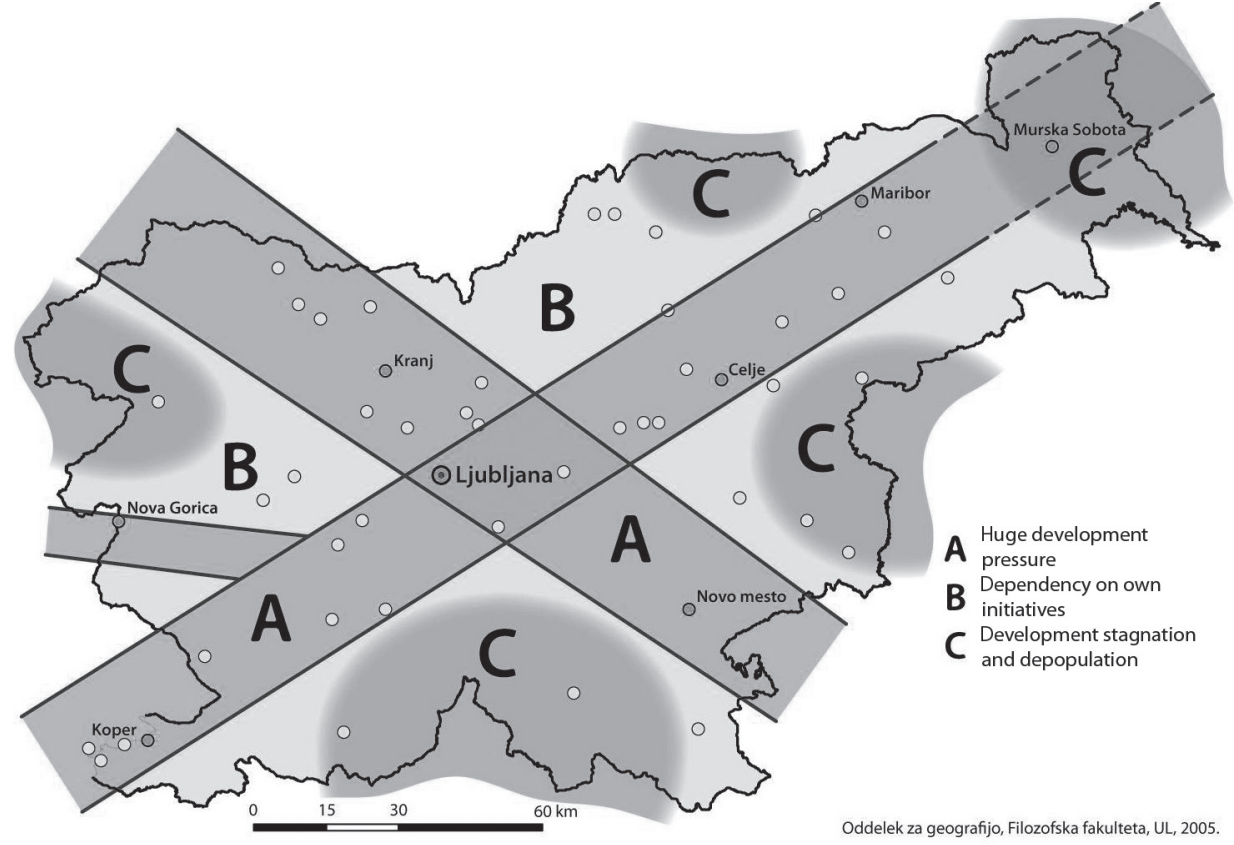

role. Due to its role in freight transport and as a seaport, Koper is also given national significance and international relevance. ${ }^{22}$

The strong overlap of a number of centralization processes in Ljubljana and the resulting relative weakening of other parts of the country have led to a half-hearted re-implementation of polycentrism that could effectively support more balanced spatial development and hinder further polarization (Potočnik Slavič 20o8, see Fig. 8). So far, Giffinger's call for making better use of the concept of polycentrism in a modern urban development concept in order to meet increasing spatial challenges (Ravbar 2005: 223) has been unheard. Clearly, Slovenian policy programs lack implementation in this respect and probably also the political ambition to install effective distributive policies hindering further polarization.

\section{Conclusions}

It is a rather new approach to perceive the emergence of peripheries and increased uneven spatial development by looking at processes of centralization, which - although being indicative - has been valuable in this paper, reviewing policy contexts and development processes in the agglomerations of Poznań and Ljubljana from a structural and social constructivist perspective. Such a perspective adds to the scientific debate by opening up the research on urban and regional development by including public discourses and images of spaces and their interrelationship with regional and national planning strategies.

Although there is space for deeper analysis, the cases show that development in Poland and Slovenia very much concentrates on the urban centers of these countries and policies for areas outside of the main agglomerations have to be seen in the light of policies for central areas. In Poland, there is an explicit strategy of strongly supporting the regions' cores in order to generate spillover effects leading to development impetus in the whole region. In recent years, however, it became obvious that only the closer catchment area profits from this kind of neoliberal policy. Ambitions to change the overall regional policy towards a more distributive policy, recognizing the role of towns and smaller cities as urban poles, have been rather weak so far and lack implementation in regional and national policies.

Contrasting Poland, Slovenia has formulated policies for balanced and polycentric spatial development. However, there is a clear deficit in setting these policies effectively into practice, and even simple infrastructure projects have been stuck for years furthering the peripheralization of regions outside the capital area and the Ljubljana-Maribor-Koper axis. Obviously, the functional centralization of Ljubljana in the context of the formation of Slovenia as an independent state and rather uncontrolled market 
powers have led to a concentration of economic, demographic, financial and administrative development impetus on the capital city of $\mathrm{Lju}$ bljana and to a lesser extent on second tier cities like Maribor and Koper.

Viewing spatial development in Slovenia and in the Poznań region from the viewpoint of polarization and peripheralization has opened alternative viewpoints on spatial development as a surplus to purely structuralist approaches. It has been fruitful to approach peripheries and processes of peripheralization by looking at the interrelationships with their centers and the respective processes of centralization. The case studies presented here provide a starting point for further research. A process-based and dynamic approach of investigating disparities should reflect views on periphery, center and their specific interrelation. In this context it might be of special importance to focus on inside perspectives of peripheralized localities and regions, also concerning strategies of resistance to externally imposed processes of peripheralization as a future research question.

Future empirical work should encompass in-depth research on the relationship between central and peripheral areas in the national context as well as discussed policy consequences for regional and national planning. It would be interesting to investigate the development and implementation of (positive) images for peripheral areas and what impact this has for the central areas. As the case of Slovenia shows, it is also necessary to research why previous attempts did not contribute to a more balanced spatial development. It would also be interesting to compare the situation between new EU Member States in Central and Eastern Europe and "old" EU Member States - here one could ask what impact EU policies might have for the construction and imagination of central and peripheral areas in a national context since several EU documents consider polycentrism an instrument for guaranteeing balanced spatial development and formulate interrelated spatial policies.

It is the perspective of viewing processes of centralization and peripheralization as being related and the combination of structural and socio-political aspects in the constitution of peripheral and central spaces that will advance the current state-of-the-art of research on spatial development issues. The concepts of peripheralization and polarization will thus help in following promising research agendas about regional development in CEE countries in the years to come.
I Parts of previous theoretical texts that have been used as a starting point for this paper are based on joint discussions as well as text contributions of partners in the iCope consortium in elaborating a $\mathrm{FP}_{7}$ proposal in 20 I 0 and 20 I. In particular, we want to thank Tomas Hanell, Irma Potočnik Slavič and Tadeusz Stryjakiewicz for their contributions and valuable comments to this paper. Further, we acknowledge the helpful comments of three anonymous reviewers.

2 For example, in terms of global integration, some bigger conurbations and metropolitan regions must be seen as peripheral, too-despite their urbanity and good accessibility.

3 Looking, for example, at the current process of spatial "categorization" (Raumtypen) in the 20 r o spatial monitoring of the German Bundesinstitut für Bau-, Stadt- und Raumforschung, specific, normatively defined thresholds have led to a particular categorization of central and peripheral spaces (BBR 2oo9). Spatial monitoring in Germany will be organized around these attributions for the next couple of years. Further, it is striking that this is based on a purely national analysis without recognizing the impact of metropolitan areas on the other sides of the border, such as Szczecin on the north-eastern part of Germany.

4 Consisting of the city of Poznan and I7 surrounding municipalities of the Poznań district.

5 In addition, the average income per capita (2009) in Pilski sub-region amounted to 2,749 zl, which was also considerably lower than the average of the voivodship $(2,976 \mathrm{zl})$ and of Poznań (3,668 zl) as well (www.stat.gov.pl).

6 Conducted as part of a PhD project at the IfL.

7 More than $60 \%$ of the Slovenian banks and insurance companies are based in Ljubljana, as well as major parts of the public administration (Hamilton 2005: 326 ).

8 The reasons for residential suburbanization development especially during the rg8os were a shortage of affordable building land (Schrenk 20 г 0 : 8 I 7-8I 8 ), a traditional affinity to rural life and home-ownership (Cerar 2oo6: 23), revitalization of inner urban areas that led to a decrease of residential use, displacement and increase of traffic problems (Stanilov 2007: 436-437) as well as a consequence of neo-liberal policies that were implemented after independence.

9 The population of Ljubljana dropped between r 99 I and r 994 from 276 , i oo to 270 , ooo, a development that took place in all Slovenian cities with a population greater than 20,000 .

Io Population numbers for 3 I December 2007 , Statistical Office of the Republic of Slovenia 2009 , www.stat.si/doc/pub/Obcine2oog/84-I o3.pdf, last visited: 5.5.20 I I.

I I It has to be noted that the administrative borders do not match the functional region of Ljubljana, 
which amounts to $350-400,000$ inhabitants in the daily catchment area.

I2 Population numbers for I. I.20 I I, Statistical Office of the Republic of Slovenia, www.stat.si/eng/ novica_prikazi.aspx?id $=3876$ and

http://pxweb.stat.si/pxweb/Dialog/Saveshow.asp, last visited: 5.I 0.20 I I.

I3 Ljubljana participates in EU projects such as Creative Cities and Second Chance, which are concerned with the promotion of creative indus tries and the revitalization of abandoned industrial areas with the help of art and culture.

I4 Since 2003, all Slovenian municipalities have to adopt new development strategies or apply existing ones (Schrenk 2010: 822).

I5 Ljubljana Urban Region (LUR) comprises 26 municipalities. It is the most densely populated region in Slovenia $\left(199 / \mathrm{m}^{2}\right)$ and has around 509 , 00o inhabitants (3 I. 12.2007),

www.rralur.si/en/region/statistical-data/. last visited: I $0.24 .20 \mathrm{II}$.

I 6 See www.rralur.si/en/, last visited: 07.27.2010.

17 The Spatial Plan of Ljubljana 2002 still designates agricultural areas in Ljubljana (Cerar 2006: 22).

I8 The Slovene Public Opinion Research (2002) revealed that 3 г. $3 \%$ of the Slovenian population prefer to live in rural areas (Ozaki 2005: io).

I9 Ljubljana belongs to the statistical region Osrednjeslovenska (Central Slovenia), which is characterized by the highest GDP per capita and population density.

20 "Ljubljana provides political, administrative, transport, cultural, and other services to all inhabitants of Slovenia, and it is developing to become an internationally competitive capital." Spatial Development Strategy of Slovenia (2004): 23.

2I The Spatial Plan of Ljubljana (2002) shows that the added value of a resident of Ljubljana is around 157 per cent higher than the added value of the rest of the Slovenian population (Cerar 2oo6: 6I).

22 Spatial Development Strategy of Slovenia (2о г o): 22-26.

\section{References}

Aligica, P.D.; Evans, A.J. (2009): The Neoliberal Revolution in Eastern Europe: Economic Ideas in the Transition from Communism (New Thinking in Political Economy). Edward Elgar Publishing.

Bański, J. (2007): Koncepcje rozwoju struktury przestrzennej w Polsce - polaryzacja czy równoważenie? Przeglad Geograficzny, 79, I: 45-79.

BBR (2009): Laufende Raumbeobachtung - Raumabgrenzungen, Raumtypen ROB 2 ого. Online: www.bbr.bund.de/nn_ro3o86/BBSR/DE/Raumbeobachtung/Werkzeuge/Raumabgrenzungen/ Raumtypen2o го/Raumtypenzo г o.html (I I April 20 II).
Beetz, S. (2008): Peripherisierung als räumliche Organisation sozialer Ungleichheit. In BarLösıus E., Neu C. (2008), Peripherisierung - eine neue Form sozialer Ungleichheit?, Berlin-Brandenburgische Akademie der Wissenschaften, Berlin, pp. ${ }^{-1} 6$.

Bıвıс̆, B. (2005): Cultural infrastructure. In Мıьонnić, A.; Breznik, M.; HrženjaK, M; Bibic̆, B. (eds.): Culture Ltd. Material conditions of cultural production, Ljubljana: Mirovni Inštitut, pp. $87-\mathrm{II} 7$.

Blowers, A.; Leroy, P. (I994): Power, Politics and Environmental Inequality: A Theoretical and Empirical Analysis of the Process of "Peripheralisation". Environmental Politics, 3, no.2 (1994): pp. 1 97-228.

Bohle, D. (2006): Neoliberal Hegemony, Transnational Capital and the Terms of the EU's Eastward Expansion. Capital \& Class 2006/3o: pp. 57-86; DOI: го.І I77/03098г6806о88оого4.

Borsig, A. (2007): Small Towns and Social Capital in the Polish Countryside. Akademia Pomorska w Stupsku (ed.): Podstawy i perspektywy rozwoju malych miast. Słupsk, pp. 227-234.

Borsig, A.; Burdack, J.; Knappe, E. (eds.) (2010): Small Towns in Eastern Europe: Local Networks and Urban Development. Beiträge zur Regionalen Geographie, 64, Leipzig.

Cerar, A. (2006): International Market of PostModern Cities. The attractiveness of post-modern cities for the creative class and knowledge workers, and promotion of urban art, Diplomsko Delo.

Commission of European Communities (2004): A new partnership for cohesion. Convergence, Competitiveness, Cooperation. Third Report on Economic and Social Cohesion, Brussels.

Dimitrovska Andrews, Kaliopa; Mihelič, B.; Stanic̆, I. (2007): The post-socialist urban restructuring of Ljubljana. Strengthening identity. In Stanilov, K. (ed.), The Post-Socialist City. Urban Form and Space. Transformations in Central and Eastern Europe after Socialism, Springer, pp. 427-445.

Dubois, A.; Gloersen, E.; Schürmann, C.; Grasland, C.; Hanell, T.; Zanin, C. (2008): Disparitäten und Kohäsion in Europa. Eine Untersuchung regionaler Entwicklungsunterschiede innerhalb der EU. RaumPlanung I36: 27-31, February 2008.

Ehruich, K. (20 I I): Creative City Ljubljana? Europeanization processes at the "edge", paper presented at the 6th InASEA conference in Regensburg, 29 April, 20 I I, unpublished.

Glówny Urząd Statystyczny (GUS) (2004): Produkt Krajowy Brutto według Województw i Podregionów w 2002 roku. Katowice.

Glówny Urząd Statystyczny (GUS) (20 Io): Produkt Krajowy Brutto. Rachunki regionalne w 2008 r. Katowice.

Harteisen, U. (2004): Slowenien. Landeskunde und Regionalmanagement, Exkursion des Masterstudienganges Regionalmanagement und Wirtschaftsförderung, 6-I3 September 2004, 
http://www.hawk-hhg.de/resource/media/ Exkursionsbericht_Slowenien.pdf, last visited: 05.10.20II.

Havlíček, T.; Chromý, P.; Jančák, V.; Marada, M. (2008): Innere und äußere Peripherie am Beispiel Tschechiens. Mitteilungen der Österreichischen Geographischen Gesellschaft, I50: 299-3 6 .

HefFner, K. (2005): Małe miasta w rozwoju obszarów wiejskich. In Heffner, K. (ed.), Małe miasta a rozwój lokalny i regionalny, Akademia Ekonomiczna im. Karola Adamieckiego, Katowice, pp. I I-34.

Hirschman, A.O. (1958): The Strategy of Economic Development. New Haven, Conn.: Yale University Press.

Hladnik, J.; Kreitmayer, J.; Vuga, T.; Zavodnik, A. (eds.) (2002): Spatial management policy of the Republic of Slovenia, prepared by National Office for Spatial Planning, Ministry of the Environment, Spatial Planning and Energy, Ljubljana.

Jatowiegki, B. (2006): Polish cities and metropolisation processes. Studia Regionalne $i$ Lokalne, Special Issue, S. 75-84.

Kaczmarek, T.; Mikula, Ł. (2007): Ustroje terytorialno-administracyjne obszarów metropolitalnych w Europie. Poznań.

Keim, K.-D. (2006): Peripherisierung ländlicher Räume.In $A P u Z 37 / 2006$; online: www r.bpb.de/ files/ 7 LIGDM.pdf ( г I April 20 г г).

Komlosy, A. (г988): An den Rand gedrängt: Wirtschafts- und Sozialgeschichte des oberen Waldviertels. Österreichische Texte zur Gesellschaftskritik, Bd. 34, Wien.

Konecka-Szydlowska, B. (2009): System miast województwa wielkopolskiego. In Czzż, T. (ed.), Regionalny wymiar województwa wielkopolskiego. Biuletyn Instytutu Geografii Społeczno - Ekonomicznej i Gospodarki Przestrzennej UAM, Seria Rozwój Regionalny i Polityka Regionalna, 9: $9^{-20 .}$

KräтKe, S. (1995): Globalisierung und Regionalisierung. Geographische Zeitschrift 83, Heft 4, pp. 207-22I.

Krugman, P. (г99 I): Geography and Trade, Leuven: Leuven Univ. Pr.

Lamprecht, M. (2004): Small towns and development of rural areas: the case of the voivodship of Lodz. European Spatial Research and Policy, vol. 2, pp. $4 \mathrm{I}-56$.

LANG, T. (2010): го Jahre Schrumpfungsdiskurs in Ostdeutschland - theoretische Perspektiven. In Altrock, U. et al. (ed.), 20 Jahre Stadt- und Regionalentwicklung und -planung seit der deutschen Wiedervereinigung (Planungsrundschau Nr. 2o). Berlin.

Leimgruber, W. (I994): Marginality and marginal regions: problems of definition. In D. Сн. СнangYi, J. Sue-Ching, L. Yin-Yun (eds.), Marginality and development issues in marginal regions. Proceedings of the IGU Study Group "Development issues in marginal regions", National Taiwan University, Taipei, pp. I-I 8.

Leimgruber, W. (2004): Between Global and Local: Marginality and Marginal Regions in the Context of Globalization and Deregulation. Aldershot: Ashgate Publishing Limited.

Ministerstwo Rozwoju Regionalnego (2006): Strategia Rozwoju Kraju 2oo7-2or5. Warszawa.

Ministerstwo Rozwoju Regionalnego (2007): $\mathrm{Na}$ rodowa Strategia Spójności. Warszawa.

Mose, I.; Brodda, Y. (2004): Neue regionale Entwicklungskonzepte für periphere ländliche Räume. Raumforschung und Raumordnung, 3/2004, pp. 206-2 I 6.

Murovec, N.; Kavaš (2010): SWOT Analysis: Status of the Creative Industries in Ljubljana.

Myrdal, G. (1957): Economic Theory and Underdeveloped Regions. New York: Harper.

Neu, C. (2006): Territoriale Ungleichheit - eine Erkundung. Aus Politik und Zeitgeschichte (APuZ 37/2006).

Organisation for Economic Co-Operation and Development (OECD) (2008): Policy Brief: Regional Development in Poland.

Online: www.oecd.org/publications/Policybriefs (20 April 20 I I).

Parysek, J.; Kotus, J. (I997): Powojenny rozwój miast polskich i ich rola w procesie urbanizacji kraju. Przeglad Geograficzny, 69, no. I/2, Warszawa, pp. 33-54.

Parysek, J.; Mierzejewska, L. (2006): Poznań. City profile. Cities, vol. 23, no. 4, pp. 29 I-3o5.

Pichler-Milanovičc， N. (2005): Ljubljana. From "beloved" city of the nation to Central European "capital". In Намгlтол, I.; Diмiтrovsкa Andrews, K.; Pighler-Milanovič, N. (eds.), Transformation of cities in Central and Eastern Europe - towards globalization, Tokio: United Nations University Press, pp. 3 I 8-363.

Pichler-Milanovic̆, N.; Zavodnik Lamovšek, A. (2010): Urban Land Use Management in Ljubljana. From Competitiveness to Sustainability or vice versa?. In Schrenk, M.; Popovich,V.V.; ZeILe, P. (eds.): REAL CORP 2 oio, Proceedings/ Tagungsband, Vienna I 8-2o May 20 Io, pp. 8 1 7 825 .

Pighler-Milanovič, N.; Zavodnik Lamovšek, A.; Drobne, S. (2011): Territorial Cohesion and Polycentric Development of Slovenia. The role of functional (urban) regions, Presentation at the Conference: What future for cohesion policy?, Bled, Slovenia, March 20 I I, pp. I-I 9.

Potoc̆Nik SLAviıc̆, I. (2008): Endogeni razvojni potenciali podeželja (Endogenous Development Potentials of Rural Areas). Doctoral Thesis. Ljubljana.

Ravbar, M. (2005): The Future of Slovenian Cities in the European Competition between Cities. "Laissezfaire" or Affirmative Action? In Giffinger, R. (ed.), Competition between cities in Central Europe: $O p$ portunities and Risks of Cooperation. Bratislava: Rond, pp. 215-233. 
Kornelia Ehrlich Leibniz-Institute for Regional Geography Schongauerstr. 9 D-o4329 Leipzig Germany k_ehrlich@ifl-leipzig.de

Agnes Kriszan Carlstraße 30 D-I 7235 Neustrelitz agnes.kriszan@gmx.de

\section{Dr. Thilo Lang} Leibniz-Institute for Regional Geography Schongauerstr. 9 D-o4329 Leipzig Germany t_lang@ifl-leipzig.de
RDA (2007): Regional Development Programme of the Ljubljana Urban Region 2007-20I3.

Rządowe Centrum Studiów Strategicznych (2005): Zaktualizowana Koncepcja Przestrzennego Zagospodarowania Kraju. Warszawa.

SснміDт, M.H. (г998): An integrated systemic approach to marginal regions: from definition to development policies. In Jusilla, H.; Leimgruber, W.; Majoral, R. (eds.), Perceptions of Marginality: Theoretical Issues and Regional Perceptions of Marginality in Geographical Spaces, Aldershot: Ashgate Publishing Limited, pp. 45-66.

Sснмітт, P. (2007): Raumpolitische Diskurse um Metropolregionen. Eine Spurensuche im Verdichtungsraum Rhein-Ruhr. Dortmund: Rohn.

Scott, A.; Storper M. (2oo3): Regions, Globalization, Development. Regional Studies, vol.37, $6 \& 7$; pp. $579^{-5} 93$.

Smętkowski, M.; Gorzelak, G. (2008): Metropolis and its Region - New Relations in the Information Economy. European Planning Studies, vol. I 6 , no. 6 : $727-743$.

Statistisches Bundesamt (ed.) (r 995 ): Länderbericht Slowenien.

Statistical Office of the Republic of Slovenia (20 io): Slovene Regions in Figures. Ljubljana. Online: www.stat.si/doc/pub/Regije-2o I o.pdf ( I I. I I. 20 I I)
Stryjakiewicz, T.; Kaczmarek, T.; Męczyński, M.; Parysek, J.; Stachowiak, K. (2007): Poznań faces the future. Pathways to creative and knowledgebased regions. ACRE-report 2.8. Amsterdam.

Szymańska, D.; Matczak, A. (2002): Urbanization in Poland: tendencies and transformation. European Urban and Regional Studies, vol.9, pp. $39-46$.

Urząd Marszalkowski WoejwódzTwa WielkopolSKIEgo (2005): Development Strategy of the Wielkopolska Region by 2020 . Poznań.

Urząd Miasta Poznania (UMP) (2009): Poznań 2008. Raport o stanie miasta. Poznań.

Urząd Statystyczny w Poznaniu (USP) (20 I oa): Rynek pracy w województwie wielkopolskim w 2oogr. Poznań.

Urząd Statystyczny w Poznaniu (USP) (20 i ob): Dojazdy do pracy w Polsce. Terytorialna identyfikacja przepływów ludnoąci związanych z zatrudnieniem. Poznań.

Weichhart, P. (2008): Neoliberalismus Meets Political Economy - Politikversagen, Entdemokratisierung und die vergebliche Hoffnung auf Governance in der Zweiten Moderne. In Bruckmeier, K.; Serbser, W.H. (eds.): Ethik und Umweltpolitik: Humanökologische Positionen und Perspektiven, pp. 2 I3-236. 